\title{
Ustvarjalnost slovenskih regij in njen vpliv na oblikovanje pokrajin
}

UDK: 353(407.4): 001.895

\author{
Janez Malačič \\ Univerza v Ljubljani, Ekonomska fakulteta \\ janez.malacic@ef.uni-lj.si
}

\section{IZVLEČEK}

\begin{abstract}
Avtor postavlja $v$ besedilu tezo, da imata izobraženost in $z$ njo povezana ustvarjalnost zelo velik vpliv na regionalno členitev nekega ozemlja in njegovo upravno razdelitev. Tezo nato obravnava, analizira in testira s pomočjo indeksa ustvarjalnosti in njegovih sestavnih delov, indeksov talenta, tehnologije in tolerantnosti (3T), za slovenske statistične regije. Indeks ustvarjalnosti je najvišji v Osrednjeslovenski regiji, preostale regije pa razen Gorenjske zelo zaostajajo. Matrica razvoja kaže, da so Osrednjeslovenska, Gorenjska, Zasavska, Obalno-kraška in Goriška regija voditeljice, Savinjska se prebija, druge pa stopicajo zadaj. V Osrednjeslovenski regiji je izrazito močna koncentracija večine elementov ustvarjalnosti. Razlika med centrom in drugimi regijami pa je razen redkih izjem prevelika. Na osnovi podatkov o indeksu ustvarjalnosti in na osnovi matrice razvoja naših statističnih regij se zdi, da bi bilo najprimerneje razdeliti Slovenijo na šest do največ osem upravnih pokrajin. Oblikovati bi jih bilo treba tako, da bi za jedra vzeli regije voditeljice in prebijajoče se regije, ki bi jim smiselno priključili druge regije ali dele regij.
\end{abstract}

Ključne besede: regionalizem, ustvarjalnost, $3 T$ indeks (indeks ustvarjalnosti, indeks talenta, indeks tehnologije), matrica razvoja.

\section{Uvod}

$\checkmark$ Sloveniji je že nekaj časa $v$ središču pozornosti politične, strokovne in najširše javnosti vprašanje oblikovanja pokrajin. To vprašanje je zelo kompleksno in ima veliko različnih pomenov. Obravnavamo ga lahko z vidika različnih strokovnih disciplin, zgodovinskega ali ekonomskega razvoja, upravne razdelitve države in regij, identitete posameznikov in prebivalstva, razmerja političnih sil in interesov ipd. 
Janez Malačič

Ustvarjalnost slovenskih regij

in njen vpliv na oblikovanje pokrajin

S Slovenci poseljeno ozemlje ni imelo nikoli sreče s pokrajinsko razdelitvijo, še posebej če gledamo z nacionalnega vidika. Različni tuji gospodarji so to ozemlje delili politično in upravno $v$ skladu s kriteriji, ki slovenskega nacionalnega interesa praviloma niso upoštevali. Še bolj pogosto pa so bili (zavestno) $v$ nasprotju z njim. Politična razdelitev je z migracijami, ki jih je povzročala, ustvarjala narodnostno mešanost, kar je še dodatno zapletalo normalen razvoj zaokroženih regij in s tem pokrajin. Celo v okviru Avstro-Ogrske kot ene države smo bili Slovenci razdeljeni med oba dela monarhije.

Vse do danes so se ohranile različne teorije, ki so zanikale slovenstvo. Najbolj znana je teorija o Vendih. Ta teorija nima danes nobenega pomena več, čeprav je $\vee$ preteklosti veliko prispevala $k$ zmanjšanju slovenskega nacionalnega ozemlja. Še zmeraj pa je zelo pomembno, da je $\vee$ naši soseščini več sorazmerno velikih mest, ki so s svojimi centralnimi gravitacijskimi vplivi ovirala krepitev sosednjih slovenskih mest. Taka mesta so npr. Zagreb, Reka, Gradec in še kakšno. Zaradi spleta različnih okoliščin so ostala zunaj naših meja tudi mesta Celovec, Beljak, Trbiž, Gorica in Trst. Vpliv slovenstva v njih se je zelo zmanjšal, še zmeraj pa je močan njihov čezmejni vpliv na rast nekaterih sosednjih slovenskih mest.

Razvoj industrije in drugih nekmetijskih dejavnosti se je na Slovenskem začel kasneje kot $v$ sosednjih avstrijskih in italijanskih pokrajinah. To je ohranjalo kmetijski značaj naših pokrajin dalj časa kot $v$ severni in zahodni soseščini in vplivalo na počasnejši razvoj izobraževanja pri nas. Izobrazbena raven Slovencev je bila nizka in $\vee$ ključnih zgodovinskih trenutkih nam je primanjkovalo izobraženih, sposobnih in nacionalno zavednih ljudi.

Našteti in drugi pomembni zgodovinski procesi in dejavniki močno vplivajo na težavnost oblikovanja zaokroženih in ekonomsko močnih regij $v$ Sloveniji, ki bi bile naravna osnova upravne razdelitve države na pokrajine. To dejstvo je $v$ zadnjih letih doživelo vsaj dva praktična testa. Prvi je bil razdelitev države na dve ali tri regije zaradi upravičenosti do črpanja sredstev razvojne pomoči Evropske unije (EU). Vlada se je $v$ težnji, da bi zadostila nekaterim kriterijem EU, odločila za povsem nenaravno razdelitev Slovenije na dve regiji, čeprav bi bila vsebinsko veliko primernejša razdelitev na tri regije.

Drugi test pa je pokrajinska zakonodaja, ki se pripravlja in bi naj uvedla upravno raven pokrajin kot vmesno raven med občino in državo. Dosedanje diskusije in politični procesi vse bolj nakazujejo, da bo Slovenija tudi pri pokrajinah 


\section{Janez Malačič \\ Ustvarjalnost slovenskih regij in njen vpliv na oblikovanje pokrajin}

šla po enaki poti kot pri občinah. Pri slednjih so prevladali lokalni mikro interesi in vodili do pogosto pretirane razdrobljenosti, ki ni samo $v$ nasprotju z zakonskimi kriteriji ampak pogosto celo z zdravim razumom. Zanimivo pa je, da je razdrobljenost največja $\vee$ najmanj razvitih predelih države, kot je npr. Prekmurje. To je po svoje tudi zelo zgovorno, saj kaže, da ekonomski in družbeni razvoj nista spletla mreže močnih vezi, ki bi povezovale večje teritorialno, ekonomsko in prebivalstveno območje $v$ homogeno in naravno celoto. Slednje bi moralo biti $v$ nacionalnem interesu Slovenije, pa tudi $v$ dolgoročnem interesu prebivalstva, ki $\vee$ takih enotah živi.

$\checkmark$ tem besedilu bomo $v$ nadaljevanju obravnavali vprašanje ustvarjalnosti slovenskih regij in njen vpliv na oblikovanje pokrajin. To vprašanje je precej ožje kot $v$ uvodu obravnavana vprašanja. Kljub temu pa je že iz uvodnih misli mogoče razbrati tezo, da ima izobraženost in z njo povezana ustvarjalnost zelo velik vpliv na regionalno členitev nekega ozemlja in njegovo upravno razdelitev. $\checkmark$ nasprotju s preteklostjo se $v$ zadnjih letih izobrazbena raven prebivalstva $\vee$ Sloveniji hitro povečuje. Investiranje $v$ človeški kapital in s tem še posebej vpis $\checkmark$ terciarno izobraževanje hitro naraščata (Malačič, 2001; SL-05, str. 126). Vpis v terciarno izobraževanje je $\vee$ generaciji, rojeni leta 1985, dosegel že 62,3\% (Resolucija, 2006, str. 19). Vse to kaže, da se z izobrazbo povezani elementi ustvarjalnosti v Sloveniji hitro krepijo.

Pri analizi bomo uporabljali pristop, ki temelji na indeksu ustvarjalnosti. Razumljivo je, da nas bodo posebej zanimali indeksi ustvarjalnosti $v$ slovenskih statističnih regijah, ki se $v$ grobem kažejo kot najpomembnejša osnova sedanjih razprav o razdelitvi Slovenije na upravne pokrajine. Besedilo se $v$ določeni meri naslanja na rezultate raziskovalne naloge, ki jo je skupina raziskovalcev iz Ekonomske fakultete Univerze $\vee$ Ljubljani pod vodstvom avtorja opravila za Službo vlade Republike Slovenije za regionalni razvoj (Malačič et al., 2005).

Vsebina besedila je razdeljena na uvod, ki mu sledi točka, katera podrobneje razloži sestavo in vsebinsko utemeljenost indeksa ustvarjalnosti. Tretja točka obravnava rezultate analize ustvarjalnosti $\vee$ Sloveniji in njenih dvanajstih statističnih regijah. $V$ četrti točki besedilo analizira pomen ustvarjalnosti za regionalno in upravno razdelitev Slovenije. Na koncu sta še sklep $v$ peti točki ter seznam literature in virov. 
Janez Malačič

Ustvarjalnost slovenskih regij

in njen vpliv na oblikovanje pokrajin

\section{Indeks ustvarjalnosti}

Ameriška avtorja Florida in Tinagli sta se lotila proučevanja ustvarjalnosti v družbi in njenega pomena za gospodarski in družbeni razvoj s pomočjo indeksa ustvarjalnosti (Florida and Tinagli, 2004). Ta je nadalje sestavljen iz treh sestavin, ki so tudi indeksi. Imenujejo se indeksi talenta, tehnologije in tolerantnosti (3T). Posamezni izmed njih pa so razčlenjeni še naprej na trojice sestavnih delov. Poglejmo si $\vee$ nadaljevanju, kako so sestavljeni posamezni izmed teh indeksov.

Indeks talenta je sestavljen iz naslednjih podatkov: a) deleža zaposlenega prebivalstva z ustvarjalnim poklicem med vsem zaposlenim prebivalstvom, b) deleža oseb z visokošolsko izobrazbo (in več) med prebivalstvom starim od 24 do 64 let in c) števila zaposlenih raziskovalcev na 1000 plačanih zaposlenih. Osebe z ustvarjalnim poklicem so $\mathrm{v}$ skladu $\mathrm{z}$ metodologijo opredeljene kot znanstveniki, inženirji, profesorji, umetniki, glasbeniki, arhitekti, menedžerji, ekonomisti in drugi, ki se ukvarjajo s snovanjem nečesa novega in širše z ustvarjalnimi aktivnostmi nasploh. Pri deležu oseb z visokošolsko oziroma univerzitetno izobrazbo smo upoštevali tudi triletne visokošolske strokovne programe. Število zaposlenih raziskovalcev na 1000 plačanih zaposlenih oseb je dobljeno na osnovi Registra zaposlenega prebivalstva Statističnega urada Republike Slovenije (SURS).

Indeks tehnologije sestavljajo indeks inovacij, ki izraža število patentov na milijon prebivalcev, indeks visokih tehnologij, ki izraža delež patentov $v$ dejavnostih visoke tehnologije na milijon prebivalcev in raziskovalno-razvojni (R\&D) indeks, ki je opredeljen kot delež izdatkov za raziskave in razvoj $v$ bruto domačem proizvodu (BDP). Za izračun indeksa tehnologije potrebujemo naslednje podatke: število vseh patentov, število visoko-tehnoloških patentov, R\&D izdatke in BDP. SURS ima te podatke le za Slovenijo kot celoto, zato je bilo treba podatke za regije posebej zbrati.

Indeks tolerantnosti sestavimo s podatki o vrednotah, a) o obnašanju oziroma strpnosti družbe do različnih manjšin, b) o prisotnosti tradicionalnih vrednot nasproti modernim vrednotam in c) o tem, koliko družba ceni individualne pravice posameznika in njegovo samoizražanje. Pri tem indeksu je največ težav $s$ podatki na regionalni ravni $\vee$ Sloveniji. Za indeks vrednot in izražanja smo dobili anketne podatke Evropske študije vrednot iz Arhiva družboslovnih podatkov. Indeks stališč sloni na tolerantnosti do drugačnih. Podatki so bili zbrani v 


\section{Janez Malačič \\ Ustvarjalnost slovenskih regij in njen vpliv na oblikovanje pokrajin}

skladu z anketo Eurobarometra. Tudi preostali podatki za potrebe tega indeksa so bili dobljeni iz raziskave Slovensko javno mnenje.

Florida in Tinagli, 2004, sta ustvarjalnost konkretizirala z natančno opredeljenimi in merljivimi kazalci. Za vsakega izmed devetih kazalcev na najnižji ravni po njuni metodologiji poiščemo teritorialno enoto z najvišjo oziroma najbolj ugodno vrednostjo. Tej teritorialni enoti dodelimo vrednost, ki je enaka številu proučevanih teritorialnih enot. Ker imamo $\vee$ naši analizi 12 slovenskih regij, je to $v$ našem primeru 12. Za vse druge teritorialne enote izračunamo vrednosti indeksa tako, da jim pripišemo vrednost med 0 in 12, izračunano kot relativno velikost glede na vrednost za teritorialno enoto z največjo vrednostjo. Npr., če ima pri nekem kazalniku teritorialna enota vrednost, ki znaša le tretjino ali šestino vrednosti, ki jo ima teritorialna enota z najvišjo vrednostjo, potem bi ta teritorialna enota dobila vrednost 4 oziroma 2. Vrednost indeksa je lahko tudi negativna, če gre za kazalnike, ki imajo lahko tudi negativne vrednosti. Vrednost za posamezno teritorialno enoto je torej odvisna od odstopanja vrednosti te teritorialne enote od vrednosti teritorialne enote z najvišjo vrednostjo.

Pri izračunavanju vmesne stopnje indeksov, torej treh omenjenih indeksov (3T), izmed katerih je vsak izračunan iz treh indeksov na najnižji ravni, je način izračuna analogen. Seštejemo dobljene vrednosti indeksov na najnižji ravni in pogledamo, katera teritorialna enota ima najvišjo vsoto. Tej bo dodeljena vrednost, ki je enaka številu teritorialnih enot. Vrednosti indeksa za preostale regije bodo določene $z$ relativnim odstopanjem njihove vsote (vrednosti indeksov na najnižji ravni) od vsote, ki jo je dosegla teritorialna enota z najvišjo vsoto.

Iz dobljenih treh indeksov na vmesni stopnji (indeksa talenta, indeksa tehnologije in indeksa tolerantnosti) izračunamo $v$ zadnjem koraku indeks na najvišji ravni - indeks ustvarjalnosti. Tega izračunamo za posamezno teritorialno enoto tako, da seštejemo njene vrednosti treh indeksov vmesne ravni in nato dobljeno vsoto delimo z maksimalno vrednostjo, ki bi jo teritorialna enota lahko dosegla, če bi imela pri vseh treh indeksih vmesne ravni najvišje vrednosti. Tehnično to pomeni, da dobljeno vsoto delimo s trikratnikom števila teritorialnih enot. Dobljeni rezultat, indeks ustvarjalnosti, je na ta način sintetični kazalec ustvarjalnosti po vseh omenjenih dimenzijah skupaj. 
Janez Malačič

Ustvarjalnost slovenskih regij

in njen vpliv na oblikovanje pokrajin

\section{Ustvarjalnost $v$ Sloveniji in njenih regijah}

$\checkmark$ prejšnji točki prikazano metodologijo indeksa ustvarjalnosti in njegovih sestavnih delov smo $v$ že omenjeni raziskavi uporabili za analizo ustvarjalnosti v Sloveniji $\vee$ primerjavi s 14 starimi članicami EU (EU-15 brez Luksemburga = EU-14) in za analizo ustvarjalnosti v 12 slovenskih statističnih regijah (Malačič et al., 2005). Tukaj ne bomo podrobneje govorili o statističnih podatkih, ki so bili potrebni za izračun obravnavanih indeksov na državni oziroma regionalni ravni. Povejmo le, da so podatki za druge države povzeti po delu Floride in Tinaglijeve. Podatke za Slovenijo in njene regije pa smo večinoma zbrali iz domačih virov ali pa pridobili iz posebnih obdelav za namene raziskave. Nanašajo se na posamezna leta iz začetka 21. stoletja. $V$ manjšem številu primerov pa so podatki tudi za zadnja leta preteklega stoletja, še posebej to velja za indeks vrednot in indeks samoizražanja. $\vee$ resnici smo pridobili najboljše in najbolj primerne podatke, kar jih je na voljo.

Ustvarjalnost $\vee$ Sloveniji v primerjavi z EU-14 bomo obravnavali tukaj zelo na kratko in brez podrobnejšega navajanja indeksov, saj bo težišče te točke analiza ustvarjalnosti $v$ regijah. Slovenija se je pri skupnem indeksu ustvarjalnosti uvrstila na 14. mesto pred Portugalsko. Če pa pogledamo indekse talenta, tehnologije in tolerantnosti, vidimo, da je zavzela naša država pri prvih dveh 12., pri tretjem pa 13. mesto. Pri indeksu talenta je naša uvrstitev $v$ skladu z 11,3 let povprečnega izobraževanja po glavi med prebivalstvom v starosti od 25 do 64 let po popisu prebivalstva 2002 (Malačič, 2006, str. 33). Po tem kazalniku Slovenija zaostaja za okrog 2,5 let za najbolj razvitimi evropskimi državami.

Z indeksom tehnologije $v$ Sloveniji ne moremo biti zadovoljni, saj pri njem veliko bolj zaostajamo za boljšimi državami EU-14 kot pri indeksu talenta. Relativne razlike so pri tem indeksu zelo velike in bo zaostajanje zelo težko nadomestiti. Naš največji zaostanek je pri visoko tehnoloških patentih. To je odraz tradicionalne strukture slovenskega gospodarstva in velikih zaostankov pri uvajanju visokih tehnologij (npr. biotehnologije, nanotehnologije, strojne in programske računalniške opreme, letalstva in vesoljske tehnologije, robotike ipd.).

Sestavine indeksa tolerantnosti so najbolj heterogene med vsemi. Slovenci smo po vrednotah $v$ evropskem povprečju, pri stališčih smo precej tolerantni do drugačnih, kar nas je uvrstilo na visoko 4. mesto med vsemi državami. Vendar to ni bilo dovolj, da bi nevtraliziralo zelo negativen vpliv 
samopodobe in samoizražanja naših ljudi. Vrednosti tega elementa so $v$ Sloveniji tako nizke, da so odločilno prispevale k naši uvrstitvi indeksa ustvarjalnosti na 14. mesto. Očitno bi bilo treba $\vee$ Sloveniji pripraviti, sprejeti in izvajati politiko, ki bi izboljšala samopodobo naših ljudi. $\vee$ zadnjih letih smo dosegli veliko uspehov in ciljev, ki bi morali dvigniti našo samozavest.

Zaradi težišča naše analize na regionalni problematiki bomo obravnavali ustvarjalnost slovenskih regij na osnovi konkretnih indeksov talenta, tehnologije in tolerantnosti (3T). Vendar nam prostor ne dopušča, da bi te tri indekse še naprej razčlenili na njihove elementarne sestavine, saj je vsak izmed njih razčlenjen še na tri sestavine najnižje ravni. $S$ te najnižje ravni bomo brez navajanja konkretnih vrednosti elementarnih indeksov uporabili le najbolj izstopajoče značilnosti razmer $v$ naših statističnih regijah, ki bodo še posebej osvetlili našo osnovno tezo $v$ tem besedilu.

Tabela 1: Indeks ustvarjalnosti in njegove posamezne sestavine (indeks talenta, indeks tehnologije in indeks tolerantnosti) v slovenskih regijah.

\begin{tabular}{|l|c|c|c|c|}
\hline Regija & $\begin{array}{c}\text { Točke indeksa } \\
\text { ustvarjalnosti }\end{array}$ & $\begin{array}{c}\text { Indeks } \\
\text { talenta }\end{array}$ & $\begin{array}{c}\text { Indeks } \\
\text { tehnologije }\end{array}$ & $\begin{array}{c}\text { Indeks } \\
\text { tolerantnosti }\end{array}$ \\
\hline Pomurska & $\mathbf{0 , 1 6}$ & 3,70 & 0,45 & 1,76 \\
Podravska & $\mathbf{0 , 4 6}$ & 6,74 & 4,36 & 5,64 \\
Koroška & $\mathbf{0 , 3 6}$ & 4,55 & 1,12 & 7,28 \\
Savinjska & $\mathbf{0 , 4 6}$ & 5,10 & 4,50 & 6,81 \\
Zasavska & $\mathbf{0 , 5 1}$ & 4,49 & 6,98 & 7,05 \\
Spodnjeposavska & $\mathbf{0 , 2 9}$ & 3,58 & 3,25 & 3,43 \\
JV Slovenija & $\mathbf{0 , 4 8}$ & 5,21 & 8,21 & 3,98 \\
Osrednjeslovenska & $\mathbf{1 , 0 0}$ & 12,00 & 12,00 & 12,00 \\
Gorenjska & $\mathbf{0 , 6 7}$ & 6,66 & 9,10 & 8,27 \\
Notranjsko-kraška & $\mathbf{0 , 2 8}$ & 4,72 & 3,13 & 2,27 \\
Goriška & $\mathbf{0 , 4 9}$ & 5,51 & 4,67 & 7,59 \\
Obalno-kraška & $\mathbf{0 , 5 6}$ & 6,77 & 2,40 & 10,86 \\
\hline
\end{tabular}

Vir: Malačič et al., 2005. 
Janez Malačič

Ustvarjalnost slovenskih regij

in njen vpliv na oblikovanje pokrajin

Slika 1: Indeks ustvarjalnosti v slovenskih regijah po padajočem zaporedju.

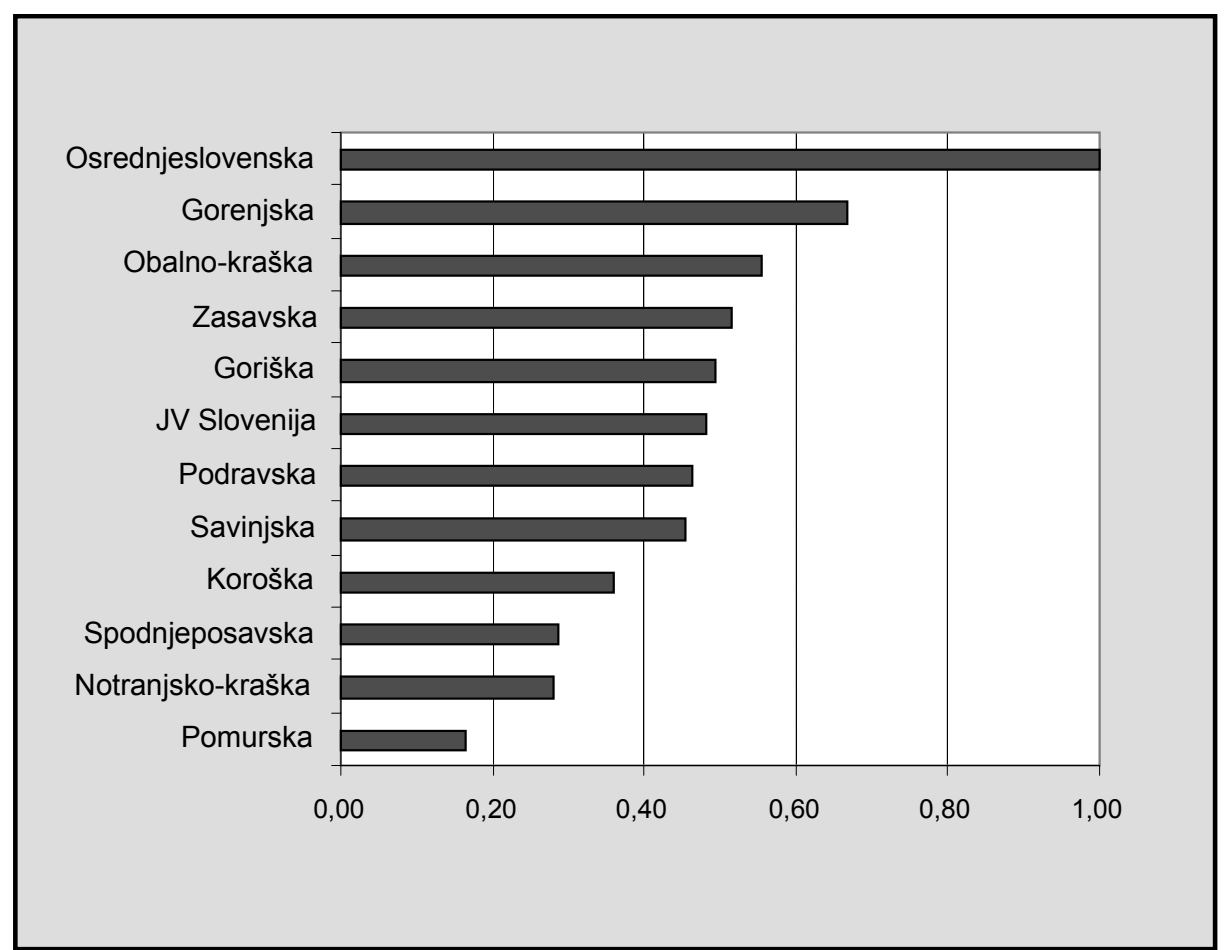

Vir: Tabela 1.

V tabeli 1 so prikazani podatki o indeksu ustvarjalnosti in indeksih 3T za vseh 12 slovenskih statističnih regij. Skupni indeks ustvarjalnosti je preračunan na vrednost 1,00, ki je $v$ Osrednjeslovenski regiji, indeksi drugih regij pa se nahajajo med 0 in 1,00. Hkrati so vrednosti tega indeksa prikazane tudi na sliki 1. Grafičen prikaz podatkov namreč veliko bolj nazorno pokaže vtis o relativnih razmerjih med posameznimi regijami, kot je to primer pri številčnih vrednostih podatkov.

Indeks talenta in njegovih sestavin je najvišji v Osrednjeslovenski regiji. Druge regije so daleč zadaj, razlike med njimi pa so precej manjše. Samo Podravska, Gorenjska in Obalno-kraška regija se povzpnejo le malo nad polovico vrednosti najvišjega indeksa. Osrednjeslovenska regija še posebej izstopa po indeksu znanstvenega talenta, ki izraža delež raziskovalcev na 1000 zaposlenih, saj ima pri tem kazalcu skoraj trikrat višjo vrednost od Podravske regije, ki je na drugem mestu. 


\section{Janez Malačič \\ Ustvarjalnost slovenskih regij in njen vpliv na oblikovanje pokrajin}

Indeks tehnologije temelji zgolj na dveh kazalcih - inovacijskem indeksu in indeksu raziskav in razvoja. Visoko tehnološke patente smo izpustili, ker jih razen občasno v Osrednjeslovenski regiji in JV Sloveniji sploh ni bilo. Na vrhu razvrstitve pri indeksu tehnologije je spet Osrednjeslovenska regija. Vendar so razlike med regijami tokrat drugačne kot pri prejšnjem indeksu. Zaostanek Gorenjske in JV Slovenije za vrhom je manjši, splošne razlike pa precej večje. Najnižje vrednosti imata Pomurska in Koroška regija, le za malenkost boljše pa so obe kraški in Spodnjeposavska regija. Ob nizkem številu patentov nasploh izstopa Pomurska regija, ki v obravnavanem obdobju ni zabeležila nobenega patenta.

Indeks tolerantnosti kaže $v$ Pomurski, Spodnjeposavski in Notranjsko-kraški regiji ter $\vee$ JV Sloveniji, da tradicionalne vrednote prevladujejo nad modernimi vrednotami. Okolje je manj naklonjeno novostim in ustvarjalnosti kot $v$ drugih regijah, kjer prevladujejo bolj moderne vrednote. Indeks samoizražanja pa razkriva, da $\vee$ Sloveniji izrazito dajemo prednost varnosti pred svobodo in pravico do samoizražanja. To velja za vse regije, razen za Osrednjeslovensko. Le v tej regiji so preference do svobode in pravice do samoizražanja rahlo pred varnostjo. Verjetno je to povezano z učinkom glavnega mesta, kjer je več odprtosti in izkušenj z drugačnimi in širšim svetom nasploh.

Če si sedaj še enkrat ogledamo skupni indeks ustvarjalnosti po regijah $v$ tabeli 1 in na sliki 1, nas ne preseneti dejstvo, da je na prvem mestu Osrednjeslovenska regija, pač pa dejstvo, da praktično vse druge regije tako zelo zaostajajo. Druga Gorenjska regija je na ravni dveh tretjin, Obalno-kraška in Zasavska regija sta nekaj nad polovico, vse preostale regije pa so pod polovico vrednosti Osrednjeslovenske regije. Zadnja Pomurska regija pa ne dosega niti petine najvišje vrednosti. Ustvarjalnost je $\vee$ Sloveniji preveč koncentrirana $\vee$ centru, zlasti obrobne in manj razvite regije pa izrazito zaostajajo.

$\checkmark$ citirani raziskavi smo izračunali še trendni indeks ustvarjalnosti, ki upošteva hitrost sprememb indeksov, ki jih vključuje indeks ustvarjalnosti. Upoštevali smo statistične in druge podatke za obdobje po letu 1995. Samo ilustrativno si na sliki 2 oglejmo še matrico razvoja za posamezne slovenske regije in $v$ nadaljevanju opredelimo značilna področja matrice razvoja.

Matrica razvoja prikazuje razporeditev regij glede na indeks ustvarjalnosti in trendni indeks ustvarjalnosti. $\vee$ matrico vrišemo navpično črto, ki kaže povprečno vrednost indeksa ustvarjalnosti, 0,48 , ter vodoravno črto, ki pomeni 
Janez Malačič

Ustvarjalnost slovenskih regij

in njen vpliv na oblikovanje pokrajin

povprečno vrednost trendnega indeksa ustvarjalnosti, 0,30. S pomočjo nastalih kvadrantov in diagonale iz zgornjega levega kota $v$ spodnji desni kot lahko razdelimo površino polja na posamezne vsebinske sklope. Površina, ki je desno od navpične ločnice in nad diagonalo, kaže voditelje. Področje levega spodnjega kvadranta in levega zgornjega kvadranta pod diagonalo je področje regij, ki stopicajo zadaj. Področje levega zgornjega kvadranta nad diagonalo je področje prebijajočih se regij, področje desnega spodnjega kvadranta pod diagonalo pa je področje regij, ki izgubljajo tla pod nogami.

Matrica na sliki 2 kaže, da praktično polovica slovenskih statističnih regij stopica zadaj. Med voditelje sodijo razen Osrednjeslovenske še Gorenjska, Zasavska, Obalno-kraška in Goriška regija. Samo ena regija, Savinjska, je na območju prebujajočih se regij, kar napoveduje, da v prihodnjih nekaj letih ne moremo pričakovati večjih pozitivnih sprememb.

Slika 2: Matrica razvoja slovenskih regij.

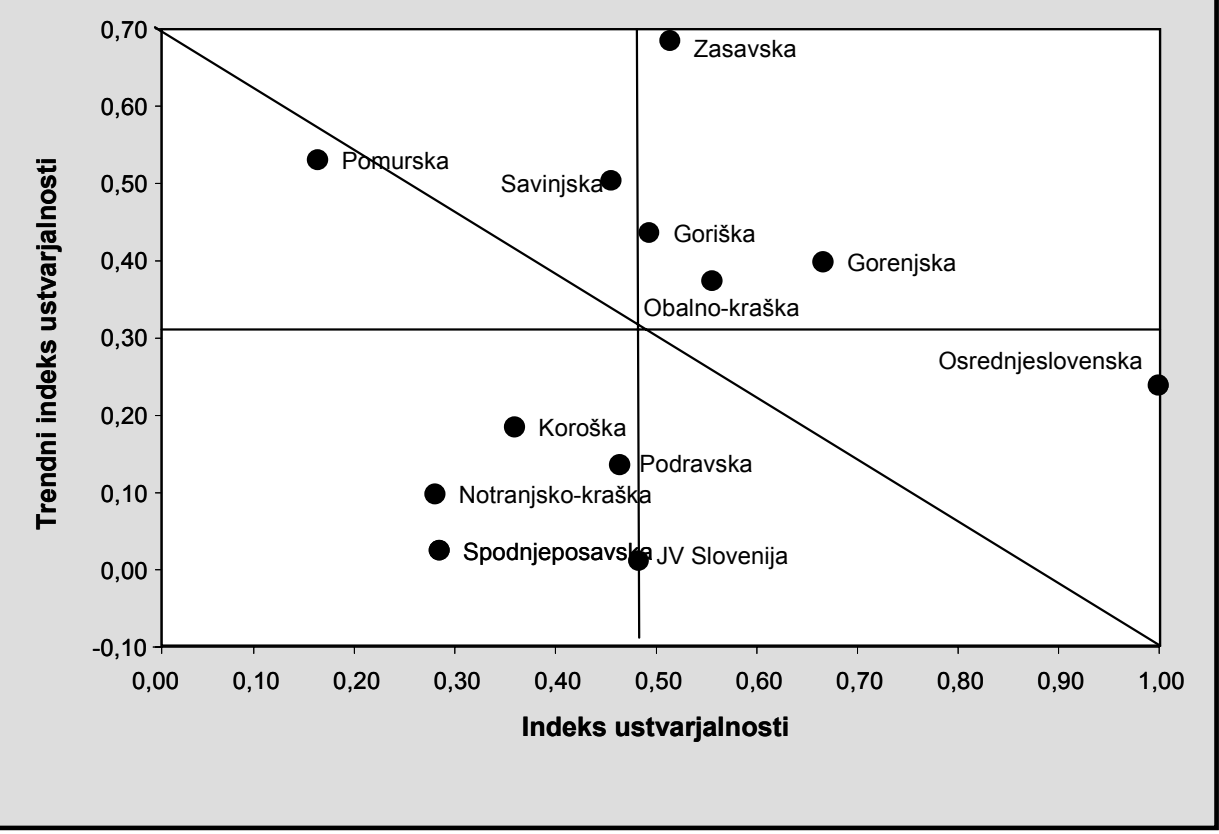

Vir: Malačič et al., 2005. 


\section{Pomen ustvarjalnosti za regionalno in upravno razdelitev Slovenije}

Posamezni elementi ustvarjalnosti, ki v sintetični obliki tvorijo indeks ustvarjalnosti, imajo velik pomen za nastajanje, krepitev in poglabljanje številnih pomembnih vezi $\vee$ prostorski razdelitvi državnega ozemlja na regije. $\vee$ Sloveniji so bili $\vee$ preteklosti mnogi izmed teh elementov prešibki ali celo popolnoma odsotni. Zato smo imeli pri nas zmeraj težave s smiselno, nacionalnim in narodno gospodarskim interesom prilagojeno regionalizacijo.

Dobro razvita regionalna razčlenjenost, ki se izraža $\vee$ gospodarski moči, samostojnosti, samozavesti ter regionalni zavesti in pripadnosti regiji, pa mora biti najpomembnejša osnova in kriterij za upravno razdelitev države. Če takšne razčlenjenosti ni, ker se $\vee$ preteklosti zaradi najrazličnejših ovir ni mogla razviti, bi jo morala regionalna politika $v$ državi načrtno spodbujati. Pri takšnem spodbujanju pa so še posebej pomembne in prelomne politične odločitve o zakonih in drugih pravnih aktih, s katerimi se ustanavljajo nove ravni upravne razdelitve. $\checkmark$ našem slovenskem primeru je to sedaj raven pokrajin.

$\checkmark$ Sloveniji po osamosvojitvi, pa tudi $\vee$ času druge Jugoslavije, upravnih pokrajin nismo poznali. Spomin na pokrajine $\vee$ prejšnjih državah in stoletjih je med našim prebivalstvom povsem zbledel, če ni že izginil. Zato sedaj $\vee$ resnici ustanavljamo pokrajine na novo. Organi, ki bodo sprejemali odločitve, pa tudi ljudje, ki so že in še bodo glasovali o tem vprašanju na referendumih, bi se morali ob tem zavedati svoje odgovornosti. Ponuja se jim priložnost, da ustanovijo smiselne, samostojne in močne pokrajine, ki bodo deloma protiutež pretirani centralizaciji države in koncentraciji skoraj vsega $\vee$ centru, deloma pa zasnova novih regionalnih vezi in omrežij, ki so bile $\vee$ Sloveniji $\vee$ preteklosti prešibke, ko pa bi jih najbolj potrebovali, jih preprosto nismo imeli.

Naša analiza ustvarjalnosti v slovenskih statističnih regijah je pokazala, da imamo v Sloveniji izrazito močno koncentracijo večine elementov ustvarjalnosti $\checkmark$ Osrednjeslovenski regiji oziroma $v$ centru. Razlika med centrom in ostalimi regijami je razen redkih izjem prevelika. Zato obstaja izrazit nacionalni interes, da se ta razlika zmanjša. Od tod sledi tudi sklep, da bi bilo 12 upravnih pokrajin, ki bi se bolj ali manj ujemale s statističnimi regijami, preveč. Na osnovi podatkov o indeksu ustvarjalnosti in na osnovi matrice razvoja naših statističnih regij se zdi, da bi bilo najprimerneje razdeliti Slovenijo na šest do največ osem upravnih pokrajin. Oblikovati bi jih bilo treba tako, da bi za jedra vzeli regije 
Janez Malačič

Ustvarjalnost slovenskih regij

in njen vpliv na oblikovanje pokrajin

voditeljice in prebijajoče se regije, ki bi jim smiselno priključili ostale regije ali dele regij.

Če pa bo prevladala politična odločitev za 12 ali celo 14 upravnih pokrajin, bomo dobili razdrobljene in šibke pokrajine, ki ne bodo premogle dovolj ustvarjalnih sil, da bi se lahko samostojno izvile iz tistega območja matrice razvoja, ki označuje enote, ki stopicajo zadaj. V tem besedilu ni prostora, da bi obravnavali številna druga vprašanja upravnih pokrajin. Gotovo so med temi še posebej pomembne pristojnosti, politična organiziranost in financiranje delovanja pokrajin. Ne glede na to, pa lahko že sedaj zapišemo, da bi bile preveč razdrobljene in šibke pokrajine še ena zamujena priložnost za oblikovanje smiselne in močne regionalne strukture, ki je temelj vsake uspešne države.

\section{Sklep}

Regionalna razčlenjenost nekega ozemlja oziroma države je rezultat številnih dejavnikov in dolgotrajnega razvoja. Hkrati se ta razčlenjenost povezuje in prepleta z upravno razdelitvijo. Tako za regionalno kot upravno členitev in njuno vitalnost pa je zelo pomemben nabor in splet elementov ustvarjalnosti. $V$ Sloveniji so ti preveč koncentrirani $v$ centralni regiji. Zato bi bilo treba zasnovati šest do osem močnih pokrajin kot protiutež centru. Samo takšne pokrajine bi imele dovolj ustvarjalnih potencialov za uspešen in trajen razvoj.

Dr. Janez Malačič je redni profesor na Ekonomski fakulteti Univerze v Ljubljani in član Katedre za statistiko ter pridruženi član Katedre za ekonomsko teorijo in politiko. Je nosilec vrste predmetov s področja ekonomika delovne sile, ekonomske demografije ter ekonomske statistike tako na dodiplomskih kot podiplomskih študijskih programih. Prof. dr. Malačič je tudi avtor ali soavtor številnih znanstvenih in strokovnih monografij in učbenikov ter avtor preko štiridesetih izvirnih znanstvenih člankov ter nekaj čez sto strokovnih člankov, ki so objavljeni tako doma kot $v$ tujini. 


\section{Literatura in viri}

- $\quad$ Florida, R. and Tinagli, I. (2004): Europe in the Creative Age, Demos, London.

- Malačič, J. (2001): Statistično ugotavljanje obsega človeškega kapitala. V: Tkačik, B., ur., Novo tisočletje - pripravljenost statistike na razumevanje in merjenje novih pojavov. 11. Statistični dnevi, SURS in SDS, Radenci.

- Malačič, J. et al. (2005): Študija o kazalcih ustvarjalnosti slovenskih regij. Služba vlade Republike Slovenije za regionalni razvoj in Ekonomska fakulteta, Ljubljana.

- Malačič, J. (2006): Demografija. Teorija, analiza, metode in modeli. 6. izdaja, Ekonomska fakulteta, Ljubljana.

- Resolucija o Nacionalnem programu visokega šolstva Republike Slovenije 2006 2010. Ministrstvo za visoko šolstvo, znanost in tehnologijo, Ljubljana.

- Statistični letopis Republike Slovenije, različni letniki, SURS, Ljubljana. 
Janez Malačič

Ustvarjalnost slovenskih regij

in njen vpliv na oblikovanje pokrajin

SUMMARY

\section{CREATIVITY OF THE SLOVENIAN REGIONS AND ITS INFLUENCE ON THE ADMINISTRATIVE PROVINCES IN SLOVENIA}

In Slovenia, the establishment of the administrative provinces has been vigorously debated political and professional topic for more than a decade. The topic is very complex and controversial. Slovenian national territory had never been lucky with the administrative divisions till the establishment of the Slovenian state at the beginning of the 1990s. The Slovenian national interests were more or less ignored or even violated under the foreign rulers in the previous centuries. Historical processes and many other factors strongly influence the complexity of the establishment of economically strong and viable regions in Slovenia which would be the natural base of the administrative provincial division of the state.

The author of the paper analyses the creativity of the Slovenian regions and its influence on the establishing of the administrative provinces. The topic is narrow one. However, the main thesis is quite obvious. It says that education and creativity are very important for the regional and administrative division of a territory. The main analytical tool in the paper is the index of creativity. In the core of the analysis are the indexes of creativity for the twelve Slovenian statistical regions. These regions are the base for the administrative provincial divisions of the country.

The American authors Florida and Tinagli have analysed the creativity in a human society and its importance for the economic and the social development by the index of creativity. The creativity index is a composite based on the talent, technology and tolerance indexes (3Ts). The 3Ts are also the composites. Each of them has three particular elements.

The talent index includes the following data:

a. the percentage of the employed population with creative occupations between all employed persons;

b. the percentage of population age 25-64 with a tertiary degree level (degrees of at least three years have been included in Slovenia) and

c. the number of research personnel per thousand employees. 
The technology index is based on three separate indicators:

a. an innovation index measures the number of patents per million populations;

b. an R\&D index measures a percentage of gross domestic product spent for research and development expenditures and

c. a high-tech innovation index measures the number of high technology patents in high technology fields such as information technology, pharmaceuticals, nanotechnology, aerospace, biotechnology, etc. per million populations.

The tolerance index includes the measures based on the values of the populations. The three measures are:

a. an attitudes index represents the percentage of tolerant persons in the society. In fact it is a measure of attitudes towards different minorities such as immigrants, gays, lesbians, etc;

b. the values index represents the degree a country or a region reflects modern or secular values as opposed traditional ones and

c. the self-expression index measures the degree to which a population values self-expression and individual rights.

The creativity index approach by Florida and Tinagli measures quantitative statistical data. It is necessary to find the region with the highest value for each of the nine indicators. The best performing region is assigned 12 points and the other regions are assigned the number of points that reflects their relative distance from the top region. The calculations of the indexes are the same at all levels. At the intermediate level we calculate the 3Ts indexes (talent, technology and tolerance). At the creativity index level the maximum value is 36 for the best performing region. For other regions we sum the values of the $3 \mathrm{Ts}$ and calculate the relative distance from the 36 .

The analysis of creativity in Slovenia has two parts. The first part compares Slovenia with EU-15 countries without Luxemburg. It is in fact EU-14. The data used for the EU-14 are from the original work of Florida and Tinagli and the data for Slovenia are calculated on the basis of Slovenian data sources. The second part covers the twelve Slovenian statistical 
Janez Malačič

Ustvarjalnost slovenskih regij

in njen vpliv na oblikovanje pokrajin

regions. The majority of the data are from the official data sources. However, some specific data have been collected for the calculations of the 3Ts indexes.

The creativity comparison between Slovenia and EU-14 can be only short here. The overall creativity index rank for Slovenia was the $14^{\text {th }}$ in the group of the 15 countries. It was placed in front of Portugal only. The results for the 3Ts are slightly different. The Slovenian ranks for the talent and the technology indexes were the $12^{\text {th }}$ in both cases while the rank for the tolerance index was the $13^{\text {th }}$. The rank of the talent index is in accordance with the educational level in Slovenia. In the census year 2002, the average schooling per person in the age group $25-64$ was 11.3 years in Slovenia. It was about 2.5 years less than in the most developed European countries.

More critical are the results in the case of the technology index. The relative distances between Slovenia and the most developed countries in Europe are much higher. Slovenia will hardly catch up in the near future, especially because the distance is the highest in the case of high technology patents. Among all three indexes the elements of the tolerance index are the most heterogeneous. The values of the Slovenians are similar to the European average. Slovenian attitudes index is as high as the $4^{\text {th }}$ in the group. However, the third element - self-expression - is very low and this fact is the basic element which placed Slovenia at the $14^{\text {th }}$ rank between 15 countries in the group.

At the regional level the maximum value of the creativity index is in the Central Slovenia region. The look at its components shows that the talent index is also the highest in the Central Slovenia region. Other Slovenian regions are well behind the first ranking region while the differences between them are smaller than in the case of the creativity index. In the case of the technology index only two elements have been taken into the calculation. These two elements are an innovation index and a research and development spending. The third element, the high technology patents, should have been dropped out of the calculation because of their absence in all of the Slovenian regions but two. These two regions are Central Slovenia and South-East Slovenia and even in these two regions high technology patents have occurred sporadically. Central Slovenia is at the top again while the distances to the Gorenjska and South-East Slovenia regions are smaller than in the case of the talent index. The two lowest ranking regions are Pomurska and Koroška 
regions. The Pomurska region did not have any patent at all in the studied period.

In four out of the twelve Slovenian regions the traditional values prevail over the modern ones. These regions are Pomurska, Lower-Posavska, Notranjsko-kraska and South-East Slovenia. In all other regions modern values are more important than the traditional values. The self-expression index shows the domination of security over the liberty, protest politics, freedom, etc. The only exception in this sense is the Central Slovenia region. It can probably be explained by the influence of the capital city and with more openness to the world.

The most striking fact in the analyses is not the first rank of the Central Slovenia but the fact that all other Slovenian regions are far behind the first one. The creativity index of the second Gorenjska region is at the level of two thirds and the indexes of the Obalno-kraška and Zasavska regions at the level which is slightly over the half of the value for the first ranking region. All other regions are far behind.

The creativity index is a static indicator. However, it is possible to include into the analysis more dynamic approach. It can be done by the calculation of the creativity trend index. This approach includes the trend data for the creativity elements in the period $1995-2003 / 2004$. The static and the dynamic approach allow us to develop the creativity matrix for the Slovenian statistical regions. The creativity matrix enables us to position the Slovenian regions in four groups. Six Slovenian regions are positioned in the group of leaders and the group of up and coming regions. In the leaders group belong Central Slovenia, Gorenjska, Zasavska, Obalnokraška and Goriška regions while in the group of up and coming regions is Savinjska region only. Other six Slovenian regions are positioned in the laggards group. These regions are Koroška, Podravska, Notranjskokraška, Lower-Posavska, South-East Slovenia and Pomurska. It is hardly possible to expect quick positive changes in the positions of the Slovenian regions in the near future.

The elements of creativity which are included in the calculation of the creativity index are very important for the establishment and strengthening of the numerous binds in the net of the territorial structure of a state and its regions. Well developed regional division which is reflected in the economic strength, independence, self-reliance and belonging to the particular territorial unit should be the most important base for the establishment of the administrative division of the country. In the case of the 
Janez Malačič

Ustvarjalnost slovenskih regij

in njen vpliv na oblikovanje pokrajin

absence of such a division, because it has not developed in the past, the regional policy in the country should have promoted it. The role of law making is especially important in the framework of such a promotion, especially when new administrative levels are introduced into the system. In the Slovenian case we have the new provincial level which has been in the process of enactment.

The introduction of the administrative provinces is important novelty in the country. All decision-makers involved and general population should be aware of the responsibility in this process. There is a chance for establishing the sensible, viable and strong provinces which could have been the counter balance to the centralization of the state and to the concentration of almost everything in the centre. The provinces could have been also the base for new binds and nets for stronger territorial units in the country. In too many examples in the Slovenian history the economic and national binds were too weak or completely absent.

The analysis of the creativity in Slovenia has shown that too many elements of the creativity are predominantly concentrated in the Central Slovenia region or in the centre of the country. The differences between the centre and other especially periphery regions are in many cases far too big. Therefore, it is in the national interest to diminish these differences. This is the basis of the conclusion that the twelve administrative provinces which would have been established along the lines of the statistical regions is simply too big number. The analysis of the creativity indexes and the creativity matrix in Slovenia and its statistical regions suggests the introduction of the six to eight administrative provinces. They should have been created along with the regions which belong to the groups of leaders and up and coming regions. Other regions or parts of the regions could have been included in such a division.

However, if the political decision for twelve or even fourteen regions will prevail, the country will be divided in weak and partitioned provinces which will not have enough strength and creative forces to escape from those areas of the creativity matrix which mark the laggards' area. Too many small and weak provinces in Slovenia would be one more missed chance in the line of historical opportunities for the establishment of the viable and strong regional structure which is the base of every successful country. 